\title{
Evaluation of conditions influencing the change of cargo turnover in Russia
}

\author{
Ludmila Goloshchapova ${ }^{1, *}$ and Natalia Savina ${ }^{1}$ \\ ${ }^{1}$ Plekhanov Russian University of Economics, 117997, Moscow, Stremyanny lane, 36, Russian \\ Federation
}

\begin{abstract}
The article presents analytical data on the assessment of cargo turnover on the territory of the Russian Federation. The purpose of the study is to analyze the dynamics of changes in the main indicators that characterize the situation in this area: transportation of goods by road, evaluation of elements of the national project "Safe and high-quality roads" and factors that influence the studied indicators. The paper uses empirical research methods: observation, comparison, and modeling. According to the results of the study, the main conditions that affect the volume of cargo turnover in the regions of Russia are highlighted.
\end{abstract}

\section{Introduction}

One of the main tasks of the Russian Federation is to maintain the territorial integrity of the country, including ensuring trouble-free and continuous interaction of the regions. The main link between the regions is the railway and road network, which also affects the investment attractiveness of the region, since it is not profitable to invest in a region that is "disconnected from the world "by the lack of developed infrastructure, because the cost of infrastructure development will have to be borne by the investor, and for him this is a large cost. Therefore, the transport system is not just an independent important part of the Russian economy, but also characterizes its state, being an indicator of consumer activity in the country [1]. That is why it is important to monitor the state of the transport sector and track changes and their trends, and identify factors of influence [2]. The following main indicators as transportation of goods by road and cargo turnover are used for this purpose.

\section{Material and methods}

In the second quarter of 2019, the value of the indicator "transportation of goods by road by organizations of all types of activities for the period from the beginning of the reporting year to the corresponding period of the previous year" was $100 \%$, significantly exceeding the values of the previous five quarters, but still not reaching the value of 103.45 , which was typical for the end of 2017 (figure 1).

\footnotetext{
* Corresponding author: cool.lvg2012@yandex.ru
} 


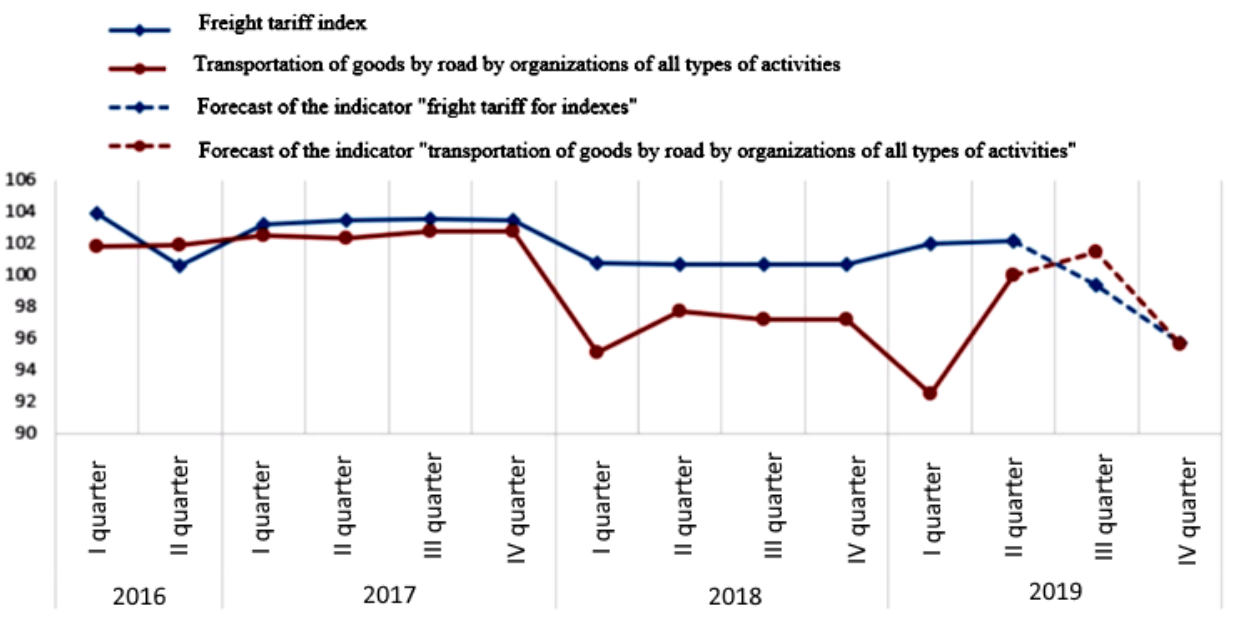

Compiled by the authors based on data [4].

Fig. 1. Dynamics of indicators of cargo transportation by road transport.

The actual value of the indicator is $2,458.7$ million tons. The freight rate has a significant impact on cargo transportation, since the correlation between these indicators for the period under review is 0.63 . However, the freight tariff index is more monotonous and exceeds the freight transport index by $2.2 \%$. This rate is calculated based on the distance between points, the quality of the road surface, repair and maintenance of the vehicle, the method of loading the car, parking the vehicle and fuel costs. The price index for the purchase of motor gasoline in the second quarter of previous year was $95.5 \%$ by the end of 2018 [3].

The North Caucasus Federal district is the regional leader in the second quarter of 2019 in terms of the "road freight index", with a value of $148.8 \%$, which in actual terms is only 787.4 thousand tons. In this Federal district, the index of tariffs for road transportation of goods did not change in June 2019 (100.3\% by December 2018, which is almost 2\% less than the average value for Russia). This result was achieved thanks to the implementation of the national project "Safe and high-quality roads" during 2017-2018 in the Makhachkala city agglomeration, and in all other subjects of the North Caucasus Federal district and in seven agglomerations in 2019. In addition, in 2019, the capacity of the Federal highway R217 "Caucasus" was increased from two to four lanes [5]. The second place is occupied by the Central Federal District with the value of $134 \%$ (16,672.5 thousand tons). This is due to the beginning of the Federal project "Europe-Western China" in 2019 with the financing of more than 3 trillion rubles, under which a new high-speed road Moscow-Kazan is being built, bypassing major cities [6]. And the third place is taken by the Siberian Federal district in terms of its $119 \%$ in terms of the indicator, while taking the first place among the Federal districts in terms of road cargo transportation in actual terms (26,216.4 thousand tons). This situation is due to the implementation of the national project "Safe and high-quality roads". Due to this project, a highly worn-out, defective road Kemerovo - Novosibirsk (where the traffic intensity is more than 5 thousand cars per day) was being repaired in 2019 [5].

The only region that has significantly conceded its position is the Urals Federal District with a value of $98.6 \%$ (6,344.8 thousand tons). The Far Eastern Federal District, whose index is $100.3 \%$ (6,344.8 thousand tons), is also lagging behind; however, in contrast to the Urals Federal District, this is not so critical for it due to the large number of sea cargo transportation. Interestingly that the biggest changes in tariffs for cargo transportation are observed in these two regions (the UFD - 103.7\%, the FEFD - 107.1\%). 
Indicator related to the transportation of goods is the turnover, because the turnover of transport means the volume of transport work on cargo transportation expressed in tonnekilometres (move 1 tonne of cargo per 1 kilometer). Compared to the first half of 2018, in the same period of 2019 , cargo turnover by road transport increased by $7.2 \%$, which is the largest increase among all types of transport (figure 2).

January-June 2019 in \% to January-June 2018

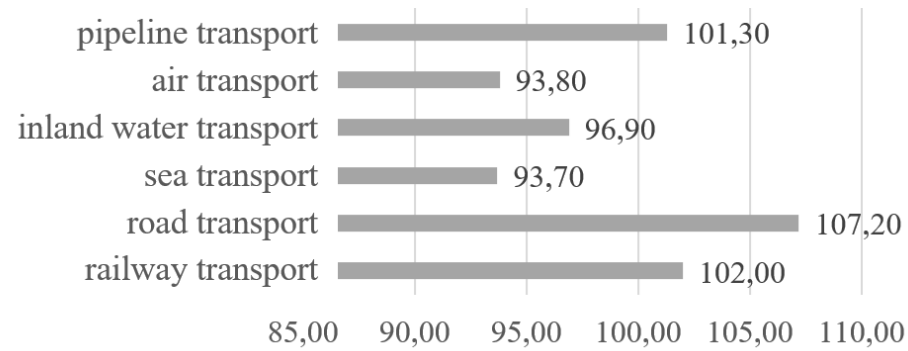

Compiled by the authors based on data [5].

Fig. 2. Change in cargo turnover of different modes of transport in January-June 2019 for the corresponding period of 2018.

Over the past 3 years, this indicator has increased (98.8\% in 2015, 110.3\% in 2018), which is due to the improvement of the economic situation in the country, the development of its own production within the framework of the policy of import substitution of goods and products. The forecast until 2023 shows an annual growth of cargo turnover in the region of $10 \%$ (figure 3 ).

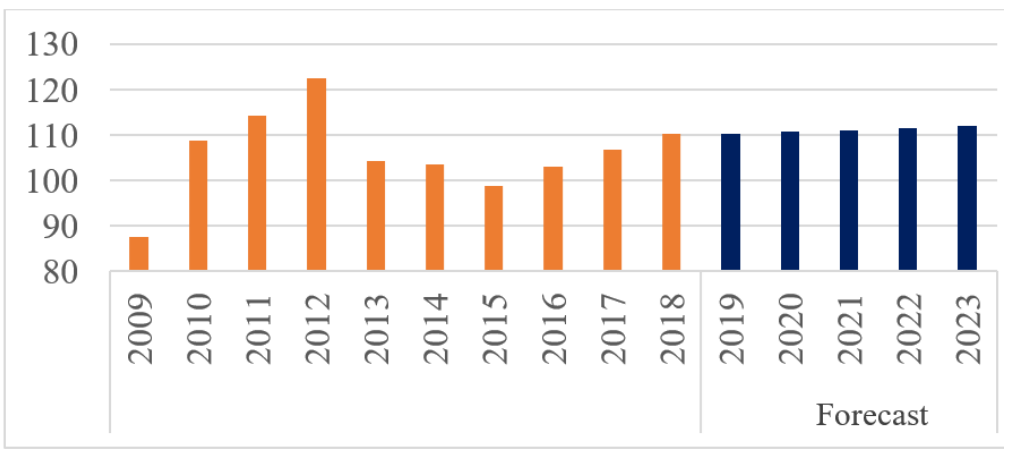

Compiled by the authors based on data $[6,7,8]$.

Fig. 3. Cargo turnover of road transport of organizations of all types of economic activity without small businesses (among enterprises that reported in the reporting period), in $\%$ to the corresponding period of the previous year.

This forecast can also be considered probable in economic terms, since the following activities are planned in the forecast period as a part of the national project "Safe and highquality roads":

1) Development of the system of automatic points of weight and size control of vehicles (ASVGC), the purpose of which is to reduce the damage caused to roads when overloaded large and heavy vehicles pass.

By the end of 2023, the system is planned to be operational in 65 regions of Russia, the total number of control points on roads will be 690 (table 1). 
Table 1. Main system development parameters. Passport of the national project "Safe and highquality roads" [9].

\begin{tabular}{|c|c|c|c|c|c|}
\hline & 2020 & 2021 & 2022 & 2023 & 2024 \\
\hline $\begin{array}{c}\text { Number of ASVGC on federal } \\
\text { roads }\end{array}$ & 10 & 182 & 282 & 387 & - \\
\hline $\begin{array}{c}\text { Number of subjects in which } \\
\text { ASVGC is located }\end{array}$ & 25 & 35 & 50 & 65 & 75 \\
\hline $\begin{array}{c}\text { Number of ASVGC on roads of } \\
\text { regional and local importance }\end{array}$ & 138 & 197 & 252 & 303 & 366 \\
\hline
\end{tabular}

Automatic points for weight and size control of vehicles are installed on a certain section of road. Special sensors and scales are built into the roadbed, and frames with accompanying equipment are located above them (fig. 4).

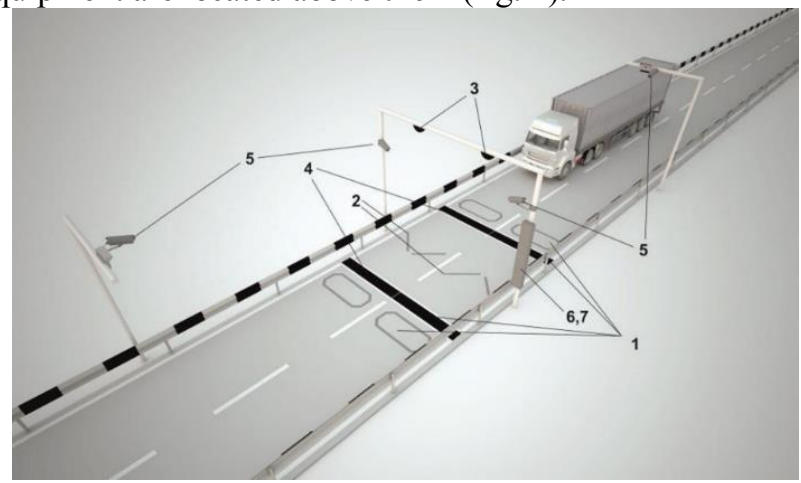

Compiled by the authors based on data [9].

Fig. 4. Scheme of the system of automatic points of weight and size control of vehicles.

This complex allows you to record the following parameters:

- module for measuring vehicle weight parameters (figure 1)

- $\quad$ multiplicity detection module (figure 2)

- $\quad$ unit of measurement of dimensional parameters of the vehicle (figure 3)

- $\quad$ vehicle speed measurement module (figure 4)

- module for recognition of the state registration mark and photo-fixation of the vehicle (figure 5)

- $\quad$ intra-system interaction module (figure 6)

- communication module (number 7)

In case of violation, the data get to the autofixation centers, where reports on administrative violations are drawn up and sent to the vehicle owner. The amount of penalty for this violation depends on the amount of vehicle overload and is from 150 to 500 thousand rubles (Table 2). 
Table 2. The amount of fines for exceeding the permissible vehicle weight or axle load capacity. Code of the Russian Federation on Administrative Offences [5].

\begin{tabular}{|c|c|}
\hline $\begin{array}{c}\text { The value of exceeding the permissible mass of the vehicle or } \\
\text { the axial load }\end{array}$ & Amount of the fine (RUB) \\
\hline $2-10 \%$ & 150000 \\
\hline $10-20 \%$ & 300000 \\
\hline $20-50 \%$ & 400000 \\
\hline More than $50 \%$ & 500000 \\
\hline
\end{tabular}

The widespread development of this system and tougher penalties will increase the volume of cargo turnover in the country, since carriers will distribute cargo to several vehicles in order to avoid receiving fines for overloading.

2) By March 1, 2023, there will be introduced electronic document management in Russia for the transportation of goods on international transport corridors. This will greatly simplify the processing of documents for export goods [8].

3) Construction of new roads and development of intermodal transport. Major projects in this area are:

- construction of the Russian section of the Meridian toll highway, which will pass through the territory of eight Russian regions from Belarus to Kazakhstan, it is planned to launch the project in 2024.

- construction of a dry cargo area at the seaport of Taman (Crimea), which will eliminate the shortage of transshipment capacity.

- construction of the first category highway Moscow - Nizhny Novgorod - Kazan, 729 $\mathrm{km}$ long, which will reduce travel time from 12 to 6.5 hours.

The main volume of cargo turnover in January-June 2019 falls on the Central and Volga Federal districts: their share is more than $54 \%$ (fig. 5).

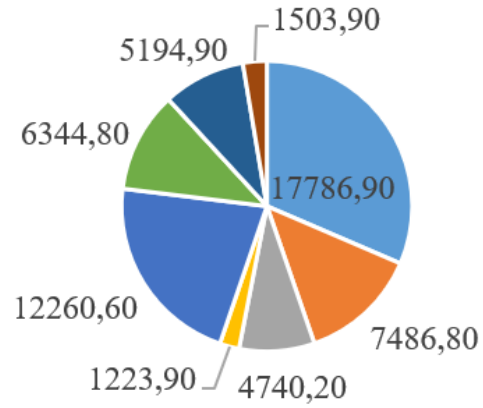

- Central Federal district

- North-Western Federal district

- Southern Federal district

- North Caucasus Federal district

- Volga Federal district

- Urals Federal district

- Siberian Federal district

- Eastern Federal district

Compiled by the authors based on data $[8,9]$.

Fig. 5. Cargo turnover of trucks of large and medium enterprises in January-June 2019 by Federal Districts of the Russian Federation. 
In the Central Federal district, the main leaders in cargo turnover are economically developed regions - Moscow and the Moscow region account for about $41 \%$ of the district's cargo turnover. In the VFD the republics of Tatarstan and Mordovia form a similar share $(40 \%)$. This is explained by the fact that these regions are actively developing automotive infrastructure, construction of new enterprises, which leads to the development of logistics. One of the main factors in these regions is the spread of techno parks focused on innovative products, the production and sale of which requires transport interaction with both domestic and foreign markets.

\section{Conclusion}

Thus, we can conclude that the transport of goods by road shows the greatest growth among all types of transport. In the first half of 2019, there is a growth in the indicators of transportation and cargo turnover by road. This is due to the improvement of the economic situation in the country, the development of Platon systems and automatic points of weight and size control of vehicles, the construction of new production facilities and logistics centers. A significant contribution is made by the implementation of the national project "Safe and high-quality roads", which includes the construction and reconstruction of roads of various levels, and measures to improve the safety of road infrastructure. The main flows of cargo turnover and cargo transportation by road are carried out in the economically developed regions of the country, located mainly in the Central and Volga Federal districts.

\section{References}

1. L.V. Goloshchapova, Transport business 4, 12-14 (2018)

2. L.V. Goloshchapova, L.A. Ivanova, Russian transport business 2, 126-129 (2017)

3. Statistics. Official Internet resource of the Ministry of Transport of the Russian Federation. https://www.mintrans.ru/ministry/results/180/documents

4. The future of Russia. National Projects. TASS News Agency. https://futurerussia.gov.ru/

5. Code of Administrative Offences of the Russian Federation Article 12.21.1. Violation of traffic regulations for heavy and (or) large vehicles. http://www.consultant.ru/document/cons_doc_LAW_34661/f727c535f35518ba16c7d5 1b782a5f6ed67b76a3/

6. L.V. Goloshchapova, N.S. Plaskova, N.A. Prodanova, S.Y. Yusupova, S.N. Pozdeeva, International Journal of Mechanical Engineering and Technology 9(11), 1897-1902 (2018)

7. National project "Comprehensive plan for the modernization and expansion of the main infrastructure". TASS News Agency. https://futurerussia.gov.ru/kompleksnyyplan-modernizacii

8. National project "International cooperation and export". TASS News Agency. https://futurerussia.gov.ru/mezhdunarodnaya-kooperaciya-i-eksport

9. Passport of the national project "Safe and high-quality roads". http://static.government.ru/media/files/rBdyoIr3S9IDP8Q871XXYaktpKWGc0NY.pdf

10. B. Kovačič, R. Kamnik, A. Pustovgar, N. Vatin. Procedia Engineering. 165. 918-925 (2016) DOI:10.1016/j.proeng.2016.11.801. 